FROM GRAIN TO PIXEL 


\section{FRAMING FIM}

FRAMING FILM is a new book series dedicated to theoretical and analytical studies in restoration, collection, archival, and exhibition practices, in line with the existing archive of the Nederlands Filmmuseum. With this series, Amsterdam University Press and the Nederlands Filmmuseum aim to support the academic research community, as well as practitioners in archive and restoration. Please see www.aup.nl for more information. 


\section{GIOVANNA FOSSATI FROM GRAIN TO PIXEL}

The Archival Life of Film in Transition 


\section{FILmmUSEUM}

enmmererm

Cover illustration: Amour et science (H.J. Roche, Éclair, France, 1912 - courtesy of the Nederlands Filmmuseum)

Cover design and lay-out: Magenta Ontwerpers, Bussum

$\begin{array}{ll}\text { ISBN } & 9789089641397 \\ \text { e-ISBN } & 9789048510696 \\ \text { NUR } & 674\end{array}$

(C) Giovanna Fossati / Amsterdam University Press, Amsterdam, 2009

All rights reserved. Without limiting the rights under copyright reserved above, no part of this book may be reproduced, stored in or introduced into a retrieval system, or transmitted, in any form or by any means (electronic, mechanical, photocopying, recording or otherwise) without the written permission of both the copyright owner and the author of the book. 
TO GLORIA 
